${ }^{1}$ Dnipro University of Technology, Dnipro, Ukraine

\title{
EMPIRICAL DEFINITION OF THE SHEARING ANGLE AND CHIP-EDGE CONTACT LENGTH WHEN CUTTING
}

\author{
(C) Ю.Г. Кравченко ${ }^{1}$, В.А. Дербаба ${ }^{1}$ \\ ${ }^{1}$ Національний технічний університет «Дніпровська політехніка», Дніпро, Україна

\section{ЕМПІРИЧНЕ ВИЗНАЧЕННЯ КУТА ЗСУВУ ТА ДОВЖИНИ КОНТАКТУ СТРУЖКА-ЛЕЗО ПРИ РІЗАННІ}

Purpose. Simplification of shearing angle determination during chip formation and improving the determination of chip-edge contact length with the corresponding derivation of new calculation empirical formulas.

Methodology. The study is based on the use of analytical and probabilistic methods for calculating the shearing angle during chip formation, the shearing angle according to an empirical formula based on the cutting force components under a fine edge and a constant value of the friction-shift ratio, which adequately corresponds to the value of the most common formula based on the chip thickening ratio.

Results. The formulas for determining the shearing angle during chip formation are obtained. Value constancy of the friction-shift ratio for certain groups of steels has been determined. Compared to steel 45 more ductile austenitic steel 12X18H9T has lower values of the friction-shift ratio. The length formula of the chip-edge contact based on the chip texture angle compared to the formula based on the chip thickening (shortening) ratio has a difference of more adequately accounting for the impact of the build-up forming phenomenon and increased metal deformation at negative rake angles. In the wake of cutting speed and rake angle rising there is a corresponding increase in the shearing angle and reduction in the contact length of chip with edge.

Scientific novelty. Functional dependances for determining the shearing angle during chip formation have been developed, which is achieved by introducing empirical dependences of the cutting force components under a fine edge on the operating and geometrical parameters of the cutting process, by establishing a constant value of the friction-shift ratio in the shear plane and corresponding formula derivation for determining the shearing angle, which excludes in each case time-consuming experiments to determine the shearing angle through the chip thickening ratio or holding the dynamometer test of the cutting force components.

Practical value. The use of empirical formulas for calculating the shearing angle and in the contact length of chip with edge on the basis of cutting force components under a fine edge makes it possible to exclude the experimental determination of the chip thickening ratio, and for account of "backward" calculation method of the cutting force components under a fine edge to refuse the timeconsuming dynamometer test of the cutting force components in each case.

Key words: edge, chip formation angle, shearing angle, cutting forces, thickening ratio, cutting speed, rake angle.

Introduction. The cutting process is characterized by such macroeconomic indicators as cutting force components, cutting temperature, tool life, strength of machined stock working surface and overall surplus cutting performance. 
The parameters of the cutting mode and edge geometry, the chip thickening (shortening) ratio, shearing angle, the length of the chip-edge contact, stress and friction ratios on the edge contact surfaces serve as element indicators of the edge cutting machining process and are used in calculating of the cutting force components, heat source density, research of contact phenomena and optimization of operating and geometric parameters of the process [1-3].

Herewith the shearing angle appears to be the main elemental indicator of the chip formation process and remains the most complicated problem of analytical calculation.

The most widespread acceptance in determining the shearing angle has acquired the formula by I.A.Time $[2,3]$

$$
\operatorname{tg} \phi=\frac{\cos \gamma}{k_{a}-\sin \gamma}
$$

based on the thickening ratio $k_{a}=a_{d} a, a=S \cdot \sin \varphi$ - cut thickness, $S$ - inflow, $\varphi-$ plan angle, $a_{c}$ - chip thickness or shortening ratio, $k_{L}=L_{c} / L, L$ i $L_{c}$ - length of cut and chip.

The disadvantages of the implementation are that, in each case, an experiment and significant labor costs are required.

Among the formulas for the contact length determination of chip with edge, the most recognized was the modified [4] formula by N.G. Abuladze [5]

$$
l_{\gamma}=a \cdot k_{a}^{0.1}\left[k_{a}(1-\operatorname{tg} \gamma)+\frac{2}{\cos \gamma}\right],
$$

which includes cut thickness $a$, chip thickening ratio $k_{a}$ and rake angle of the edge $\gamma$.

The disadvantage of the formula is inadequacy of the determination results, especially under build-up forming on the front surface and at negative rake angles of the edge.

Problem statement. The purpose of simplifying the method for determining the shearing angle during chip formation is achieved by introducing empirical dependences of the cutting force components under a fine edge on the operating and geometric parameters of the cutting process, by establishing a constant value of the friction-shift ratio in the shear plane and corresponding formula derivation for determining the shearing angle, which excludes in each case time-consuming experiments to determine the shearing angle through the chip thickening ratio $[2,3]$ or holding the dynamometer test of the cutting force components [2,3].

A new formula to improve the method of contact length determination of chip with edge has been derived, which includes an additional parameter of the chip formation process, such as the chip texture angle, which in its turn is determined through the shearing angle and relative displacement $[2,3]$.

The original basis for determining the tangent $P_{z}$, radial $P_{y}$ and axial $P_{x}$ of the cutting force from the cutting mode (depth $t$, inflow $S$, speed $V$ ) and edge geometry (rake angle $\gamma$, rounded corner $r$, wear rate $h$ along the frank surface) was the developed combined equations $[6,7]$ of the type

$$
P_{i}=c_{p} \cdot t^{x} \cdot S^{y} \cdot V^{z} \cdot(1-\gamma / 90)^{\eta} \cdot(1+r)^{v} \cdot(1+h)^{u} \cdot k_{p i}
$$


with the accumulated exponential quantities $x$ - $u$, dimensional proportionality ratio $c_{p}$ and correction indexes for brand $k_{M}$ and strength $k_{\sigma}$ of processed material, grade tool material $k_{i}$, of the plan angle $k_{\varphi}$ and slope of the main cutting edge $k_{\lambda}$ and lubricatingcooling environment $k_{o}\left(k_{p i}=k_{M} \cdot k_{\sigma} \cdot k_{i} \cdot k_{\varphi} \cdot k_{\lambda} \cdot k_{o}\right)$.

For non-rectangular cutting conditions, the normal component of the cutting force is

$$
P_{n}=\sqrt{P_{y}{ }^{2}+P_{x}{ }^{2}} .
$$

Such structure of combined equations (3) makes it possible to calculate the forces $P_{z}^{\prime} i P_{n}^{\prime}$ under a fine edge $(r=0$ i $h=0)$ by the "backward" calculation method.

The main body. The solution has two sections:

1. Determination of the shearing angle $\Phi$ during chip formation [16]. The calculation model for determining the shearing angle $\Phi$ is shown in Fig. 1: $a$ i $a_{c}-$ cut and chip thickness; $\gamma$-rake angle of the edge; $T_{s}$ i $T_{n}$-tangential and normal projection of the resultant chip formation force $T$ on the cutting plane $P_{n}$ and the reference plane $P_{v}$; $P_{z}^{\prime}$ i $P_{n}^{\prime}$-tangential and normal components of the cutting force under a fine edge (the value of wear land $h$ and frictional force along the edge frank surface are theoretically zero).

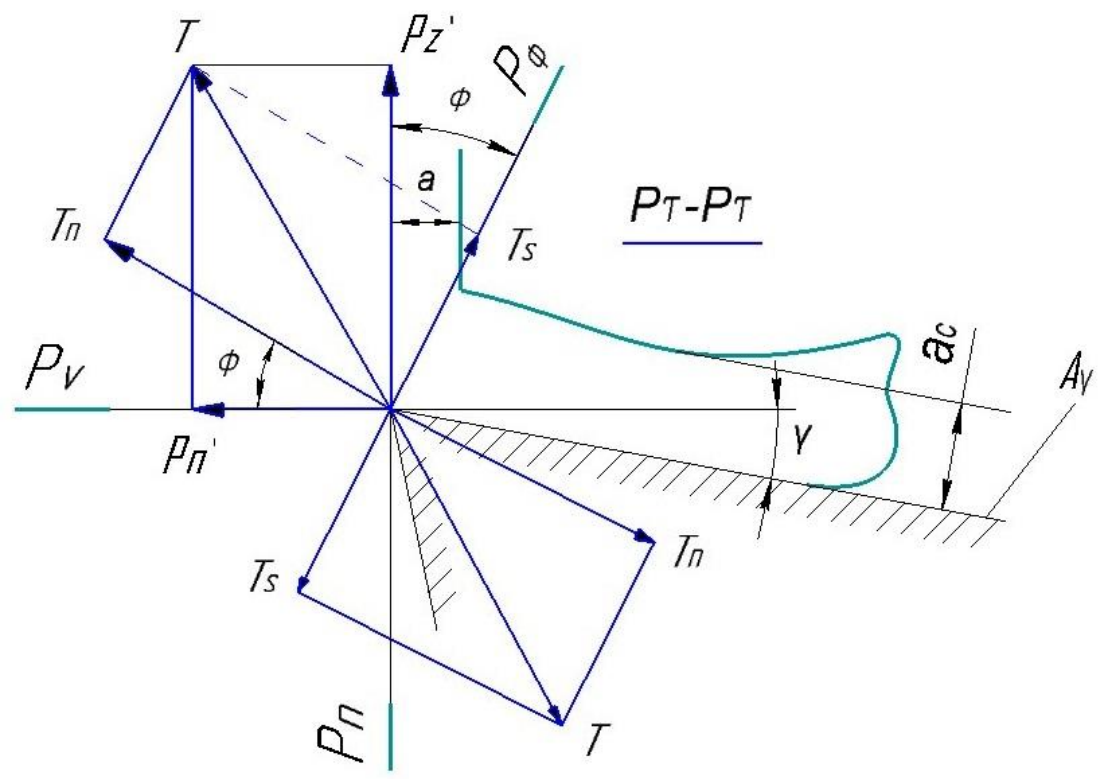

Fig. 1. Location of the chip formation force projections $T$ and shearing angle $\Phi$ in the coordinate system of the reference plane $P_{v}$, cutting plane $P_{n}$ and the reference secant plane $P_{\tau}$

According to the diagram in Fig. 1 there is a connection between the components of the shearing force $T_{s}, T_{n}$ and the cutting force under a fine edge $P_{z}^{\prime}, P_{n}^{\prime}$ through the shearing angle $\Phi[8,16]$. The friction-shift ratio $\mu_{S}$ formula is derived from the projection of the forces $P_{z}^{\prime}$ i $P_{n}^{\prime}$ in direction to the tangent $T_{s}$ and normal $T_{n}$ shearing forces.

$$
\left.\begin{array}{l}
T_{s}=P_{z}{ }^{\prime} \cdot \cos \phi-P_{n}{ }^{\prime} \cdot \sin \phi \\
T_{n}=P_{z}{ }^{\prime} \cdot \sin \phi+P_{n}{ }^{\prime} \cdot \cos \phi
\end{array}\right\} \text {, from which }
$$




$$
\mu_{s}=\frac{T s}{T n}=\frac{P z^{\prime}-P n^{\prime} \cdot \operatorname{tg} \phi}{P z^{\prime} \cdot \operatorname{tg} \phi+P n^{\prime}} .
$$

Analysis of the obtained results of a series of experiments table. 2 and 3 at $\Phi$ (1) and calculations $P_{z}^{\prime}(3)$ and $P_{n}^{\prime}(4)$ showed a constant ratio value $\mu_{S}=$ const (5) for individual groups of processed materials.

According to $\mu_{S}(5)$ the shearing angle is determined from the relation

$$
\operatorname{tg} \phi=\frac{\mathrm{P} z^{\prime}-P_{n} \cdot \mu_{s}}{\mathrm{P} z^{\prime} \cdot \mu_{s}+P n^{\prime}},
$$

where $P^{\prime}{ }_{z}$ i $P_{n}^{\prime}$-empirical values of the tangent and normal components of the cutting force under a fine edge; $\mu_{s}-\mathrm{a}$ constant value of the friction-shift ratio.

2. Determination of chip-edge contact length

The model for determining the contact length of chip $l_{\gamma}$ with edge rake face $A_{\gamma}$ is shown in Fig. 2: $P_{V}$ and $P_{n}$-coordinate reference and cutting planes; $\gamma$ - edge rake angle; $\Phi$ and $P_{\phi}-$ angle and plane of shear; $\psi$ and $P_{\psi}$ - angle and plane of texture.

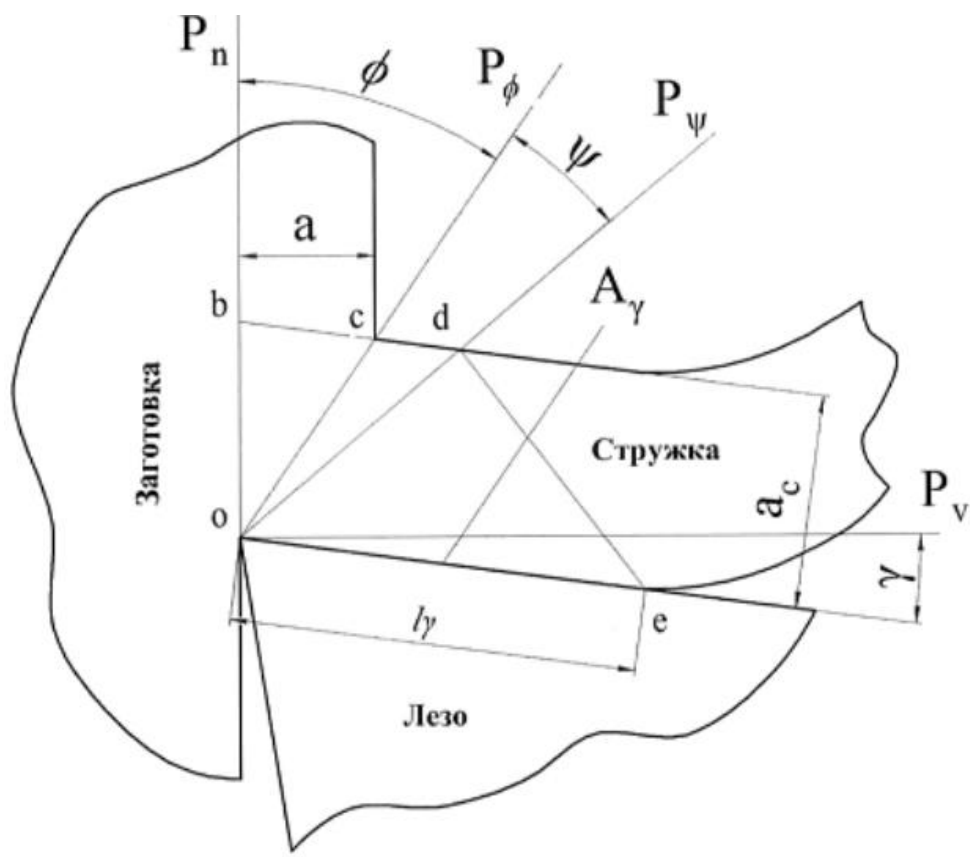

Fig. 2. The calculation model for determining the contact length of chip with edge $l_{\gamma}$ : a - cut thickness; $\Phi$ - shearing angle; $\gamma$ - rake angle; $\psi$ - texture angle

This chip formation scheme is adopted on the basis of well-known researches by the method of instant stopping of the cutting process followed by the manufacture of microsection root chips $[2,9,15]$.

Furthermore E. Lee and B. Schaffer $[8,10,14]$ saw that under the load from the tool, there must be a stress field inside the chip itself, which transfers the cutting forces from the shear plane to the edge face surface.

The primary deformation begins in the zone of the plane $P_{\phi}$ and ends in the plane $P_{\psi}$, where axes from distorted elements with an initial square shape under the action of 
normal stresses become linear $o d$. The braking force of the chip flow on the bearing surface $A_{\gamma}$ lead the near-edge zone $o e$ to secondary deformation.

As far as is known, in both zones, deformation is accompanied by chip material strengthening, the elasticity field of which is limited by rectangular leg de to the texture plane $P_{\psi}$.

The angle of chip texture after shear deformation is determined by the formula known in the plasticity theory $[2,3]$

$$
\operatorname{tg} \psi=\frac{2}{\varepsilon+\sqrt{\varepsilon^{2}+4}}
$$

where $\varepsilon$ - relative shift under transformations of cut layer to chips.

In its turn, for relative shift there are expressions [2,3]

$$
\varepsilon=\frac{1}{\operatorname{tg} \Phi}+\operatorname{tg}(\Phi-\gamma)=\frac{k_{\mathrm{a}}{ }^{2}-2 k_{\mathrm{a}} \cdot \sin \gamma+1}{k_{\mathrm{a}} \cdot \sin \gamma},
$$

for which the shearing angle is predetermined according to the formula $\operatorname{tg} \Phi(1)$ through chip thickening ratio or according to the formula $\operatorname{tg} \Phi(6)$ through the cutting force components $P_{z}^{\prime}$ and $P_{n}^{\prime}$ under a fine edge and a constant value of the friction-shift ratio $\mu_{s}$.

The simulation of the length determining $l_{\gamma}$ was carried out with account for three triangles obc, ocd, ode (fig. 2)

$2.1 \Delta o b c$. From the initial conditions $\angle o b c=90-\gamma$ and afterwards $\angle b c o=90+\gamma-\Phi$.

$2.2 \Delta o c d$. The angle $\angle o c d=90-(\gamma-\Phi)$, and with account for the angle $\psi$ we get $\angle c d o=90-(\phi-\gamma+\psi)$. The share plane length $o c=l_{\phi}=a / \sin \Phi$.

From the proportion $\frac{l_{\Phi}}{\sin \angle c d o}=\frac{l_{\psi}}{\sin \triangle o c d}$ the texture plane length is

$$
o d=l_{\Phi}=\frac{a \cdot \cos (\Phi-\gamma)}{\sin \Phi \cdot \cos (\Phi-\gamma+\psi)} .
$$

$2.3 \Delta o d e$. The angle $\angle o d e=90^{\circ}$ as prearranged and then $\angle d o e=90-(\Phi+\psi)+\gamma$. With known $l_{\psi}$ i $\angle d o e$ the length $l_{\gamma}$ is

$$
o e=l_{\gamma}=\frac{l_{\psi}}{\cos \angle d o e} .
$$

The final search length of a contact is determined from the relation

$$
l_{\gamma}=\frac{2 a \cdot \cos (\Phi-\varphi)}{\sin \Phi \cdot \sin [2(\Phi-\gamma+\psi)]} .
$$

Implementation and analysis. To test the efficiency of the derived formulas $\Phi(6)$ and $l \gamma(9)$, a series of corresponding experiments was carried out during turning of the steels 45 and $12 X 18 H 9 T$ with different levels of machinability.

Empirical dependences $P i$ (3) for determining cutting force components [2, 6, 7, $11,12]$ are given in the Table 1. 
Table 1

Values of the ratios $c_{p}$ for steels $45(\sigma=750 \mathrm{MPa}$, hard alloy metal T15K6) and $12 X 18 H 9 T(\sigma=600 \mathrm{MPa}$, hard alloy metal $B K 8)$ and exponential quantities $x$ - both at $\varphi=45^{\circ}, \lambda=0$ and dry cutting $\left(k_{p}=1\right)$

\begin{tabular}{|l|c|c|c|c|c|c|c|c|}
\hline Force name, $H$ & \multicolumn{2}{|c|}{$c_{p}$} & $x$ & $y$ & $-z$ & $\eta$ & $v$ & $u$ \\
\cline { 2 - 9 } & $\begin{array}{c}\text { steel } \\
45\end{array}$ & $\begin{array}{c}\text { steel } \\
12 X 18 H 9 T\end{array}$ & $\begin{array}{c}t, \\
\mathrm{~mm}\end{array}$ & $\begin{array}{c}S, \\
\mathrm{~mm} / \mathrm{rev}\end{array}$ & $\begin{array}{c}V, \\
\mathrm{~m} / \mathrm{s}\end{array}$ & $\begin{array}{c}1- \\
\gamma / 90\end{array}$ & $\begin{array}{c}1+r, \\
\mathrm{~mm}\end{array}$ & $\begin{array}{c}1+h, \\
\mathrm{~mm}\end{array}$ \\
\hline Tangent $P_{z}$ & 1,560 & 1,790 & 1 & 0.75 & 0.15 & 1.1 & 0.1 & 0.4 \\
\hline Radial $P_{y}$ & 620 & 809 & 0.9 & 0.6 & 0.3 & 2.8 & 0.3 & 1.4 \\
\hline Axial $P_{x}$ & 437 & 460 & 1 & 0.5 & 0.4 & 2.4 & -0.2 & 1.2 \\
\hline
\end{tabular}

Experimental conditions and research results for the angle $\Phi$ according to the Formulas (1) and (6) and contact length of chip-edge $l \gamma$ according to the Formulas (2) and (9), depending in the cutting speed $V$ and rake angle $\gamma$ are given in the tables 2 and 3.

Table 2

Calculated values of the shearing angle $\Phi$ and contact length of chip with edge $l_{\gamma}$ when dry turning of steel 45 with hard alloy metal $T 15 K 6(t=2.8 \mathrm{~mm}, S=0.35$ $\mathrm{mm} / \mathrm{rev}$, cut thickness $a=0.25 \mathrm{~mm}, r=0, h=0$ )

\begin{tabular}{|c|c|c|c|c|c|c|}
\hline \multirow{2}{*}{\multicolumn{3}{|c|}{$\begin{array}{r}\text { Parameter identifiers } \\
\text { A. Speed effect } V \cdot \mathrm{m} / \mathrm{s}\left(\gamma=10^{\circ}\right)\end{array}$}} & \multicolumn{4}{|c|}{ Determination results } \\
\hline & & & 0.5 & 1.25 & 2 & 2.75 \\
\hline \multirow{2}{*}{\multicolumn{3}{|c|}{$\begin{array}{l}\text { Thickening ratio } k_{a} \\
\text { Shearing angle } \Phi \text {, degree (1) }\end{array}$}} & 2.7 & 2.2 & 2 & 1.9 \\
\hline & & & 21.3 & 25.9 & 28 & 29.7 \\
\hline \multirow[t]{2}{*}{ Cutting force components, $H$} & \multirow{2}{*}{\multicolumn{2}{|c|}{$\begin{array}{l}\text { Tangent } P_{z}^{\prime}(3) \\
\text { Normal } P_{n}^{\prime}(4)\end{array}$}} & 1936 & 1688 & 1575 & 1499 \\
\hline & & & 1032 & 751 & 640 & 574 \\
\hline \multirow{2}{*}{\multicolumn{3}{|c|}{$\begin{array}{l}\text { Friction-shift ratio } \mu_{s}(5) \\
\text { Shearing angle } \Phi, \text { degree }(6), \mu_{s}=0.83\end{array}$}} & 0.86 & 0.85 & 0.83 & 0.82 \\
\hline & & & 22.3 & 26.3 & 28.2 & 29.4 \\
\hline \multirow{2}{*}{\multicolumn{3}{|c|}{$\begin{array}{l}\text { Relative shift } \varepsilon(8) \\
\text { Texture angle } \psi \text { degree }(7)\end{array}$}} & 2.76 & 2.34 & 2.20 & 2.10 \\
\hline & & & 17.9 & 20.2 & 21.1 & 21.7 \\
\hline \multirow{2}{*}{\multicolumn{2}{|c|}{ Contact length $l_{\gamma}, \mathrm{mm}$}} & (2) & 1.18 & 1.04 & 0.99 & 0.96 \\
\hline & & (9) & 1.57 & 1.15 & 0.99 & 0.95 \\
\hline \multicolumn{3}{|c|}{ Б. Rake angle influence $\gamma$, degree $(V=2 \mathrm{~m} / \mathrm{s})$} & -10 & 0 & 10 & 20 \\
\hline \multirow{2}{*}{\multicolumn{3}{|c|}{$\begin{array}{l}\text { Thickening ratio } k_{a} \\
\text { Shearing angle } \Phi \text {, degree (1) }\end{array}$}} & 2.5 & 2.25 & 2 & 1.75 \\
\hline & & & 20.2 & 24 & 28 & 33.7 \\
\hline \multirow[t]{2}{*}{ Cutting force components, $H$} & \multirow{2}{*}{\multicolumn{2}{|c|}{$\begin{array}{l}\text { Tangent } P_{z}^{\prime}(3) \\
\text { Normal } P_{n}^{\prime}(4)\end{array}$}} & 2011 & 1791 & 1575 & 1358 \\
\hline & & & 1164 & 880 & 640 & 450 \\
\hline \multirow{2}{*}{\multicolumn{3}{|c|}{$\begin{array}{l}\text { Friction-shift ratio } \mu_{s}(5) \\
\text { Shearing angle } \Phi \text {, degree }(6), \mu_{s}=0.83\end{array}$}} & 0.83 & 0.83 & 0.83 & 0.78 \\
\hline & & & 20.2 & 24.2 & 28.2 & 32 \\
\hline \multirow{2}{*}{\multicolumn{3}{|c|}{$\begin{array}{l}\text { Relative shift } \varepsilon(8) \\
\text { Texture angle } \psi, \text { degree }(7)\end{array}$}} & 3.30 & 2.69 & 2.20 & 1.75 \\
\hline & & & 15.6 & 18.3 & 21.1 & 24.4 \\
\hline \multirow{2}{*}{\multicolumn{2}{|c|}{ Contact length $l_{\gamma}, \mathrm{mm}$}} & (2) & 1.36 & 1.15 & 0.99 & 0.86 \\
\hline & & (9) & 1.25 & 1.13 & 0.99 & 0.90 \\
\hline
\end{tabular}


Table 3

Calculated values of the shearing angle $\Phi$ and contact length of chip with edge $l_{\gamma}$ when dry turning of steel $12 X 18 H 9 T$ with hard alloy metal $B K 8(t=2.8 \mathrm{~mm}$, $S=0.44 \mathrm{~mm} / \mathrm{rev}$, cut thickness $a=0.31 \mathrm{~mm}, r=0, h=0$ )

\begin{tabular}{|c|c|c|c|c|c|c|}
\hline Paramet & ter id & & & ermina & 1 result & \\
\hline A. Speed effect $V$ & $V, \mathrm{~m} / \mathrm{s}$ & $\left.5^{\circ}\right)$ & 0.5 & 1 & 1.5 & 2 \\
\hline Thickening ratio & & & 2 & 1.8 & 1.7 & 1.65 \\
\hline Shearing angle $\Phi$ & $D$, deg & & 29 & 32 & 33.8 & 34.8 \\
\hline Cutting force & Tang & (3) & 2458 & 2206 & 2027 & 1995 \\
\hline components, $H$ & Norn & (4) & 1,174 & 920 & 812 & 738 \\
\hline Friction-shift rati & $\mu_{s}($ & & 0.71 & 0.71 & 0.70 & 0.70 \\
\hline Shearing angle $\Phi$ & $D, \mathrm{deg}$ &,$\mu_{s}=0.71$ & 29.1 & 31.2 & 32.8 & 34.3 \\
\hline Relative shift $\varepsilon$ ( & & & 2.05 & 1.91 & 1.83 & 1.80 \\
\hline Texture angle $\psi$, & degre & & 22.1 & 23.2 & 23.7 & 24 \\
\hline Contact length $l_{\gamma}$, & $\mathrm{mm}$ & (2) & 1.20 & 1.11 & 1.05 & 1.02 \\
\hline & & (9) & 1.30 & 1.13 & 1.06 & 1.02 \\
\hline $\begin{array}{l}\text { 5. Rake angle inf } \\
(V=1.5 \mathrm{~m} / \mathrm{s})\end{array}$ & fluenc & & -5 & 5 & 15 & 25 \\
\hline Thickening ratio & & & 2.3 & 2 & 1.8 & 1.6 \\
\hline Shearing angle $\Phi$ & $D, \operatorname{deg}$ & & 22.6 & 27 & 32 & 37.5 \\
\hline Cutting force & & $P_{z}^{\prime}(3)$ & 2872 & 2541 & 2206 & 1954 \\
\hline components, $\mathrm{H}$ & & $P_{n}^{\prime}(4)$ & 1748 & 1298 & 920 & 636 \\
\hline Friction-shift rati & io $\mu_{s}$ & & 0.73 & 0.73 & 0.71 & 0.67 \\
\hline Shearing angle $\Phi$ & $D$, deg & $\mu_{s}=0.71$ & 23.3 & 27.6 & 31.2 & 36.6 \\
\hline Relative shift $\varepsilon$ & & & 2.92 & 2.35 & 1.91 & 1.52 \\
\hline Texture angle $\psi$, & degre & & 17.2 & 20.2 & 23.2 & 26.3 \\
\hline Contact length $l_{\gamma}$, & $\mathrm{mm}$ & (2) & 1.52 & 1.27 & 1.11 & 0.99 \\
\hline & & (9) & 1.43 & 1.27 & 1.13 & 1.04 \\
\hline
\end{tabular}

Data analysis for angle $\Phi(6)$.

When determining the angle $\Phi(6)$ the constancy of the friction-shift ratio $\mu_{s}(5)$ value was found, the average value of which is $\mu_{s}=0.83$ for the steel 45 and $\mu_{c}=0.71$ for the steel $12 X 18 H 9 T$.

Compared to experimental data of the angle $\Phi(1)$, the empirical definition results of the angle $\Phi(6)$ based on the cutting components $P_{z}^{\prime}$ and $P_{n}^{\prime}$ under a fine edge showed close coincidence ( $3 \%$ for the steel 45 and $1 \%$ for the steel $12 X 18 H 9 T$ ).

The received data adequacy by formulas $\Phi(1)$ and $\Phi(6)$ points to appropriateness of the angle determining $\Phi(6)$ through empirical values of the tangent $P_{z}^{\prime}(3)$ and normal $P_{n}^{\prime}(4)$ of the cutting force components under a fine edge and through predetermined constant friction-shift ratio $\mu_{s}(5)$.

Data analysis by contact length $l_{\gamma}(9)$. 
The data comparison according to a well-known formula $l \gamma(2)$ and to the derived Formula $l \gamma(9)$ with texture angle $\psi$ showed in most cases close (up to $1-5 \%$ ) coincidence of the results obtained for both formulas in the presence of two differences in the determination accuracy:

at low cutting speeds $V$ for the known formula, significant reduction of length value $l \gamma(2)$ was found out, especially for the case of turning of the steel 45 at $V=0.5$ $\mathrm{m} / \mathrm{s}$ with build-up forming on the surface $A \gamma$ (by $25 \%$ );

at negative angles $\gamma$ the formula $l \gamma(2)$ leads to overestimated values of the length by $6-9 \%$.

A new relation of chip formation parameters with texture angle $\psi(7)$ was found and without the chip thickening ratio more adequately ("sensitively") takes into account the features of build-up forming and enhanced metal deformation at negative rake angles. It also provides more accurate determination of the contact length $l \gamma(9)$, including using the empirical value of the shearing angle $\Phi(6)$.

Therefore, new formulas for calculating the shearing angle $\Phi$ chip-edge contact length $1 \gamma$ were derived on the basis of empirical dependences of the cutting force components under a fine edge on the parameters of the cutting process.

The novelty of the work is protected by a patent for a utility model [7] and a patent for an invention [13].

The proposed direction of calculations includes the use of a sufficiently developed information base of technical literature on the force dependences of the cutting process for most of the processed materials.

\section{Conclusions.}

1. Value constancy of the friction-shift ratio for certain groups of steels has been determined. Compared to steel 45 more ductile austenitic steel $12 X 18 H 9 T$ has lower values of the friction-shift ratio.

2. The shearing angle according to an empirical formula based on the cutting force components under a fine edge and a constant value of the friction-shift ratio adequately corresponds to the value of the most common formula based on the chip thickening (shortening) ratio.

3. The length formula of the chip-edge contact based on the chip texture angle compared to the formula based on the chip thickening (shortening) ratio has a difference of more adequately accounting for the impact of the build-up forming phenomenon and increased metal deformation at negative rake angles.

4. In the wake of cutting speed and rake angle rising there is a corresponding increase in the shearing angle and reduction in the contact length of chip with edge.

5. The use of empirical formulas for calculating the shearing angle and in the contact length of chip with edge on the basis of cutting force components under a fine edge makes it possible to exclude the experimental determination of the chip thickening ratio, and for account of "backward" calculation method of the cutting force components under a fine edge to refuse the time-consuming dynamometer test of the cutting force components in each case. 


\section{References}

1. Зорев, Н.Н. (1956). Вопросы механики процесса резания металлов. Машгиз.

2. Бобров, В.Ф. (1975). Основы теории резания металов. Машиностроение.

3. Мазур, М.П., Внуков, М.П. \& Доброскок, В.Л. (2010). Основи теорії різання металів (М.П. Мазура (заг. ред.)). Новий світ - 2000.

4. Розенберг, Ю.А. (2001). Методы аналитического определения степени деформации металла стружки при резании. Вестник машиностроения, 3, 34-38.

5. Лоладзе, Т.Н. (1982). Прочность и износостойкость режущего инструмента. Машиностроение.

6. Кравченко, Ю.Г., Дербаба, В.А \& Крюкова, Н.В. (2015). К вопросу эмпирического определения напряжений и коэффициентов трения при стружкообразовании. Резание и инструмент в технологических системах: Междунар. науч.-техн. сб. - Харьков: НТУ «ХПИ», 85, $137-148$.

7. Кравченко, Ю. Г., \& Дербаба, В. А. (2020). Спосіб визначення кута зсуву при стружкоутворенні (Патент No. 140418).

8. Армарего, И.Д. \& Браун, Р.Х. (1977). Обработка металлов резанием. Машиностроение.

9. Грановский, Г.И. (1985). Резание металлов: учебник. Высш. шк.

10. Малышев, В.И. (2011). Очерки истории науки о резании материалов: монография. ТГУ.

11. Резников, Н.И., Жарков, И.Г. \& Зайцев, В.М. (1960). Производительная обработка нержаваеющих и жаропрочных материалов. Машгиз.

12. Косилова, А.Г. \& Мещеряков, Р.К. (1985). Справочник технолога-машинострочтеля. В 2-х томах. T2 - 4-е изд. Машиностроение.

13. Кравченко, Ю.Г., Дербаба, В.А. \& Пугач Р.С. (2020). Спосіб визначення довжини контакта заливної стружки з лезом (Патент о. 118302).

14. Пацера, С.Т., Ружин, П.О., Дербаба, В.А. \& Корсун, В.И. (2016). Алгоритм імітаційностатистичного дослідження контрольно-вимірювальної системи та його програмна реалізація у Ni LabVIEW. Системи обробки інформації. - Харківський університет Повітряних Сил ім. І.Кожедуба., 6(143), 116-119.

15. Кравченко, Ю.Г., Дербаба, В.А. \& Смагін, Д.В. (2020). Визначення і взаємозв'язок кутів зсуву і тертя при стружкоутворенні. Збірник наукових пращь Наџіонального гірничого університету, 61, 193-201.

https://doi.org/10.33271/crpnmu/61.193

16. Zhuravel, O . Yu., Derbaba, V.A., Protsiv, V.V., \& Patsera, S.T. (2019). Interrelation between Shearing Angles of External and Internal Friction During Chip Formation. Solid State Phenomena. Materials Properties and Technologies of Processing, (291), 193-203.

https://doi.org/10.4028/www.scientific.net/SSP.291.193

\section{АНОТАЦЯ}

Мета. Спрощення визначення кута зсуву при стружкоутворенні і удосконалення визначення довжини контакту стружка-лезо з відповідним виводом нових розрахункових емпіричних формул.

Методика. Дослідження базується на застосуванні аналітико-ймовірнісних способів розрахунків кута зсуву при стружкоутворенні, кута зсуву по емпіричній формулі на основі складових сили різання при гострому лезі і постійному значенні коефіцієнта тертя-зсуву, що адекватно відповідає розрахунковим значенням найбільш розповсюдженої формули на основі коефіцієнта потовщення стружки.

Результати. Одержані формули визначення кута зсуву при стружкоутворенні. Установлено постійність значення коефіцієнта тертя-зсуву для окремих груп сталей. В порівняні зі сталлю 45 більш пластична аустенітна сталь 12Х18Н9Т має менші значення коефіцієнта тертя-зсуву. 
Формула довжини контакту стружка - лезо на основі кута текстури стружки в порівнянні 3 формулою на основі коефіцієнта потовщення (вкорочення) стружки має відмінність більш адекватно ураховувати вплив явища наростоутворення та підвищеної деформації металу при негативних передніх кутах. По мірі росту швидкості різання і переднього кута леза відбувається відповідне збільшення кута зсуву та зменшення довжини контакту стружки з лезом.

Наукова новизна. Розроблені функціональні залежності для визначення кута зсуву при стружкоутворенні, що досягається введенням емпіричних залежностей складових сили різання при гострому лезі від режимних і геометричних параметрів процесу різання, установленням постійного значення коефіцієнта тертя - зсуву в площині зсуву і виводу відповідної формули визначення кута зсуву, що виключає в кожному випадку трудоємких експериментів по визначенню кута зсуву через коефіцієнт потовщення стружки або проведенню динамометрування складових сили різання.

Практична цінність. Застосування емпіричних формул розрахунку кута зсуву і довжини контакту стружки з лезом на основі складових сили різання при гострому лезі дозволяє виключити експериментальне визначення коефіцієнта потовщення стружки, а за рахунок метода «зворотного» розрахунку складових сили різання при гострому лезі відмовитися від трудоємкого динамометрування складових сили різання в кожному випадку.

Ключові слова: лезо, кут стружкоутворення, кут зсуву, сили різання, коефіцієнт потовщзення, швидкість різання, передній кут.

\begin{abstract}
АННОТАЦИЯ
Цель. Упрощение определения угла сдвига при стружкообразовании и совершенствование определения длины контакта стружка-лезвие с соответствующим выводом новых расчетных эмпирических формул.
\end{abstract}

Методика. Исследование базируется на применении аналитико-вероятностных методов расчетов угла сдвига при стружкообразовании, угла сдвига по эмпирической формуле на основе составляющих силы резания при остром лезвии и постоянном значении коэффициента трениясдвига, адекватно отвечает значению наиболее распространенной формулы на основе коэффициента утолщение стружки.

Результаты. Полученные формулы определения угла сдвига при стружкообразовании. Установлено постоянство значения коэффициента трения-сдвига для отдельных групп сталей. В сравнении со сталью 45, более пластична аустенитная сталь 12 Х18Н9Т имеет меньшие значения коэффициента трения-смещения. Формула длины контакта стружка - лезвие на основе угла текстуры стружки по сравнению с формулой на основе коэффициента утолщение (укорочение) стружки имеет отличие более адекватно учитывать влияние явления наростоутворення и повышенной деформации металла при отрицательных передних углах. По мере роста скорости резания и переднего угла лезвия происходит соответствующее увеличение угла сдвига и уменьшение длины контакта стружки с лезвием.

Научная новизна. Разработанные функциональные зависимости для определения угла сдвига при стружкообразования, что достигается введением эмпирических зависимостей составляющих силы резания при остром лезвии от режимных и геометрических параметров процесса резания, установлением постоянного значения коэффициента трения - смещения в плоскости сдвига и вывода соответствующей формулы определения угла сдвига, исключает в каждом случае трудоемких экспериментов по определению угла сдвига через коэффициент утолщения стружки и проведения динамометрирования составляющих силы резания. 
Практическая ценность. Применение эмпирических формул расчета угла сдвига и длины контакта стружки с лезвием на основе составляющих силы резания при остром лезвии позволяет исключить экспериментальное определение коэффициента утолщение стружки, а за счет метода «обратного» расчета составляющих силы резания при остром лезвии отказаться от трудоемкого динамометрирования составляющих силы резания в каждом случае.

Ключевые слова: лезвие, угол стружкообразования, угол сдвига, силь резания, коэффициент утолщения, скорость резания, передний угол. 